\title{
Loss and damage due to climate change: attribution and causation - where climate science and law meet
}

\author{
Roda Verheyen \\ Rechtsanwälte Günther, \\ Mittelweg 150, 20148 Hamburg, Germany \\ Email: verheyen@rae-gunether.de
}

\begin{abstract}
The short paper scrutinises the concept of legal causation in the context of 'detection and attribution' and discusses the approaches of law and climate science to causation. It looks at the issue both with respect to the climate regime's agenda item of 'loss and damage' and with respect to a specific tort-like or nuisance-based case.
\end{abstract}

Keywords: causation; detection and attribution; science; law; FCCC.

Reference to this paper should be made as follows: Verheyen, R. (2015) 'Loss and damage due to climate change: attribution and causation where climate science and law meet', Int. J. Global Warming, Vol. 8, No. 2, pp.158-169.

Biographical notes: Roda Verheyen is an Attorney in a private law firm specialised on environmental, energy and planning law in Hamburg, Germany. Clients include non-governmental organisations, private entities and communities. She has been working in the field of climate change and energy law for more than 15 years, including as a member of the delegation of Germany in the UNFCCC negotiations. In 2002 she co-founded the network Climate Justice Programme, which continues to work on bringing climate change to courts worldwide. Her $\mathrm{PhD}$ 'Climate change damage in international law' (2005) continues to be one of the major academic works on the issue. She is a board member of the Hamburg International Environmental Law Conference (http://www.hielc.com).

\section{Introduction ${ }^{1}$}

In this journal, many aspects of 'loss and damage due to climate change' will be discussed, with respect to all its various dimensions and aspects and also as an item in international negotiations.

With the UN FCCC Conference of the Parties' establishment of the Warzaw mechanism on loss and damage (Decision 2/CP.19, FCCC/CP/2013/10/Add.1) ${ }^{2}$, preceded by the Doha decision on the topic (Decision 3/CP.18) states accept that there is or will be some level of loss due or at least contributed to by anthropogenic climate change, some level of change 'beyond' adaptation, even if this might not be the exact framing.

Yet, natural science literature and this issue of the Journal of Global Warming also holds contributions which show the scientific problems to attribute anthropogenic climate change to specific events or even losses and the practical problems of delineating 
adaptation and 'loss and damage', i.e., damage, that cannot or is not prevented through adaptation. This short paper is about the role and importance of climate science or forensics through a legal lenses.

It should be said at the outset that 'loss and damage' is not the same as legal liability or state responsibility for damage (Verheyen, 2005; Roderick and Verheyen, 2008; Lefeber, 2012) and as an issue, it is not set within a certain tort-like case, but has been conceived in the much broader setting of the UN FCCC (see the relevant paper by Stabinsky and Hoffmaister, 2014). While loss and damage are both terms that can be understood legally (Verheyen, 2012), they are understood in the present scientific community simply to refer to what lies beyond the limits of adaptation, acknowledging that such limits will not be easily determined. Whether or not adaptation measures are undertaken and are successful depend on many choices and circumstances, but this is a topic for a separate reflection.

As a practising lawyer, one is often asked if a claim seeking damages or compensation for loss/damage, or injury due to climate change is possible. The answer is not easy, but should in general be affirmative. The underlying scepticism involves mostly three issues:

1 Who would be the 'polluter' or defendant given that everybody emits greenhouse gases,

2 What is the relevant behaviour ('fault'), assuming fault is needed for a claim and given that emitting greenhouse gases is not illegal per se;

3 How do you show causation between emissions of that polluter and the specific injury, for example the costs for raising dyke levels, larger water storage tanks for irrigation purposes or the re-settlement of an entire village. In other words: how would you attribute not only certain phenomena or events but the actual loss?

In this paper, I try to look at the last question only. This involves difficult questions of scientific possibilities, legal framing and value judgements. It is also to some extent a question for any future climate regime, i.e., the Warzaw mechanism on loss and damage. It delineates the scope under which the climate regime might be the competent forum to deal with issues of loss and damage.

\section{How much forensics/scientific evidence do we need?}

Looking at climate science through a legal lense immediately indicates that there are very different scientific needs depending on what one is trying to use it for.

When attempting to close a regulatory gap at the international or national level or even for designing a mechanism with compensatory elements for losses, one might have to use climate science to

- disentangle natural risks from climate change in general

- disentangle national policies or lack of from as contributing factor of 'disasters' 
- disentangle responsibilities of nation states from individuals

- identify thresholds or parameters of dangerous change

- establish ways of capturing non-economic losses.

Yet, in these cases one is looking at a rather 'political' burden of proof, a more macro-level approach to capturing legally the contribution of climate change to whatever category of damage the regime might be seeking to regulate.

When looking at the role of science in a case-specific context, the burden of proof will be full and placed on whoever is a plaintiff in any particular case. This will involve using climate science to

- select a specific defendant out of the multitude of 'polluters', deal with the problem of time lag between emissions and impacts, address the issue of contribution of the chosen defendant ('pick and choose')

- link a specific event or change to anthropogenic climate change (general causation)

- link the specific loss to that event or change (specific causation).

and generally produce evidence that will convince a court on the basis of the quasi universal principle in civil law that the plaintiff has to present his case to the satisfaction of the court. In this context a lawyer might seek to divide a causation chain in the way indicated above, i.e., into general and specific causation [Verheyen, (2005), p.254 ff.; Haritz, (2010), pp.212 ff; Frank, (2013), p.30].

In their recent volume on climate litigation, Brunnée et al. (2012, p.33) have argued, that "a statistical approach may ... provide sufficient proof", which indicates that there might be several approaches to show causation. Given its existence as a tool in climate law, for both fields of application (regime and case specific), the question is whether the emerging field of 'attribution and detection' can ever prove causation in the normative sense.

But as indicated above, only a case specific approach will necessarily have to look for very specific modelling science as evident in the so-called fingerprint-studies ${ }^{3}$. Fingerprint studies take a specific event or phenomenon (e.g., floods in the south of England) and statistically evaluate the chance that this event would have occurred without the human signal, i.e., anthropogenic climate change (Allen and Stott, 2003).

A broader approach within the climate regime will not necessarily need such detailed studies. What could be done, for example, is generate certain local or regional thresholds of change which will then be 'deemed' to be due to climate change. Such an approach would reflect the fact that an anthropogenic signal can be more comfortably attached to trends of change than to specific events. Also, if an international mechanism on loss and damage were to support risk sharing instruments such as insurance tools, no attribution in the sense of linking anthropogenic climate change to a specific event (such as a flood or heatwave) or slow-onset change (sea level rise) might be needed at all.

Thus, the fact that there possibly are limits to statistical evidence and modelling attribution in this sense (explained below) should therefore not serve as a shield to developing solutions to the fact that climate change is and will increasingly become a driver of physical damage and loss associated with it around the world. 


\title{
3 Causation vs. 'detection and attribution'
}

Causation and causality are in fact scientific (natural sciences) not legal terms. This is where the theories of science, philosophy and law meet. While determining a question of law is based on linear reasoning and logic, explaining and determining facts or real-life incidents is normally nonlinear and relies on a set of assumptions. Very often, natural science cannot determine cause-effect relationships with $100 \%$ certainty but is rather focused on ruling out certain relationships, i.e., falsifying rather than verifying. This is certainly the case for the climate system, which is highly nonlinear. It is also true for the many cases involving toxics or drugs, where scientists find only a high likelihood that certain substances cause injury in human beings or the environment. This section seeks to set out the difference between law and climate science in looking at 'causation'.

\subsection{What is detection and attribution?}

There is a scientific debate and activity of detection and attribution of climate change, which is often equated with the search for proving causation of climate change. The IPCC Guidance defines this as follows:

\begin{abstract}
"Detection of change is defined as the process of demonstrating that climate or a system affected by climate has changed in some defined statistical sense without providing a reason for that change. An identified change is detected in observations if its likelihood of occurrence by chance due to internal variability alone is determined to be small' (Hegerl et al., 2010). The guidance note defines attribution as 'the process of evaluating the relative contributions of multiple causal factors to a change or event with an assignment of statistical confidence." (Stocker et al., 2013)
\end{abstract}

Chapter 10 of the current fifth IPCC Assessment Report, Working Group I provides a summary of the state of science about 'Detection and attribution of climate change: from global to regional' with lead authors that have conducted the already mentioned 'fingerprint studies' aimed at linking specific extreme weather events to anthropogenic climate change.

In this chapter, the IPCC tells us for example:

\begin{abstract}
"Human influence has been detected in the major assessed components of the climate system. Taken together, the combined evidence increases the level of confidence in the attribution of observed climate change, and reduces the uncertainties associated with assessment based on a single climate variable. From this combined evidence it is virtually certain that human influence has warmed the global climate system." (p.871)
\end{abstract}

This relates to what can be called 'general causation', i.e., whether human behaviour actually contributes to/'causes' changes at all.

With respect to specific phenomena the IPCC Working Group II Chapter 18 'Detection and attribution of observed impacts' [Field et al., (2014), Vol. 1] first qualifies:

"Only some robust attribution studies and meta-analyses link responses in physical and biological systems to anthropogenic climate change."

but then summarises that scientific evidence of a human 'fingerprint' is best with respect to 
- near surface temperatures

- free atmosphere temperatures

- ocean temperatures

- northern hemisphere snow cover and sea ice extent.

These changes show 'distinctive regional patterns consistent with the expected fingerprints of change from anthropogenic forcing'. For example, it is 'very likely' human influence has contributed to the observed changes in temperature extremes since the mid-20th century. Also, the physical and chemical properties of oceans (including the extent of Arctic sea ice) have changed significantly over the past six decades, 'due to anthropogenic climate change' (WG II, Chapter 18.3.3).

On the other hand, this cannot be said to date with respect to

- drought

- changes in tropical cyclone activity

- $\quad$ antarctic warming

- antarctic mass balance.

From these statements flows an essential understanding for a lawyer or policy maker which might be obvious to the climate scientist: there is no objective, model-free observation of climate - not of mean changes, nor of extreme weather events. All scientific interferences about climate involve a combination of models and observations [Allen, (2012), p.8].

In principle, therefore, there is no difference between stating a cause for the mean temperature rise in the last millennium ('general causation') or for a specific flooding event ('specific causation'). Distinctions between general and specific causation in the legal sense might be useful on a case-specific-bases, but for climate scientists, there is no 'step-wise' approach.

Therefore, when arguing a climate case in court there will never be a scientifically credible witness answering, 'yes, this mean change in temperature or this extreme event was caused by anthropogenic interference with the climate system'. The statement will always come as a statement of probability, as are the IPCC statements above.

Thus, for example, the existing credible studies looking at particular extreme events (the UK floods of 2000, the European heatwave of 2003 and the Russian heatwave of 2010) as reviewed in IPCC WG II Chapter 18 all conclude that human drivers have increased the likelihood of the event occurring by $\mathrm{x} \%$, but the authors would still have to answer 'yes', complimented by a statement of how likely this is, when asked in court whether it is possible that the event might have happened without any anthropogenic climate change added to the natural variability. This has been stressed by authors such as Myles Allen and Mike Hulme in various publications. So - where does this link in with legal concepts of causation? 


\subsection{What is causation?}

From a legal perspective, attribution of human conduct to a certain outcome is the core of all arguments in environmental law - climate change is no exception. For a lawyer seeking damages for or prevention from harm from polluters in particular, only those risks or losses human beings cause will form the basis of a case, while - with every case - there will be many other causes or factors that have lead to the specific damage.

Naturally, the general societal risks, here: natural variability of the climate system, are not negligible for the law in that - at least in many societies around the world - the state will assume a sort of duty of protection towards its citizens against known risks, as well as - to some extent - a duty to minimise impacts of disasters through social safety nets or specific aid programs. Yet, as soon as a problem can be pinpointed to a human agent acting wrongly the law will seek to 'hold responsible'. This is the tort-like situation envisaged by many when discussing loss and damage due to climate change.

In terms of the concept of causation, anthropogenic climate change is more complex than most other causes of environmental damage, in that multiple causes and actors contribute to a certain outcome (increased GHG concentrations) and because there is no clear beginning or end point.

Yet, showing causation in climate change to a certain event is not necessarily more complicated, I would argue, than in certain toxics or medical cases (asbestos, tobacco), where lawyers and scientists have had to disentangle the millions of causes why a human body acts as it does from the working of a certain substance. In these cases, as in climate change, there is no absolute answer, no 'right' or 'wrong' but rather it is a matter of a court believing in a scientific statement of probabilities. In such cases as with climate change, scientists or doctors would not be able to rule out that cancer might have occurred in the specific person also without any interference from toxic substances. The real difference in these cases is that they normally offer a clearer view on the 'polluter' than we might assume in climate change [Brunnée et al., (2012), p.5].

Taking a step back, therefore, what is causation in legal theory and practice?

Establishing causation in law means establishing a particular relationship between a certain legally relevant behaviour by an individual or other entity (be it a private legal entity or a state) and a loss or injury in a specific legal setting and under the preconditions set by law.

The concept of 'causation' is a tool to determine what kind of legally relevant behaviour will be covered by the specific rule. That is also why the concept of causation is in effect heavily normative, this in turn depending on the legal norm in question.

Lawyers and courts have therefore established certain causation 'tests' that will be applied in specific cases, applying specific provisions of tort law, nuisance or other types of causes of action. German law is used as an example here, only to display an example of what would be needed:

As in common law jurisdictions, German law applies a two-fold test for causation [Koch et al., (2012), p.376 ff]. A distinction is made between the question of causal relationship in the logical or scientific sense between the action and the loss (causation) and the further question of whether it is justified to hold the person who has caused the loss responsible (accountability) (Staudinger and Kohler, 2010).

It is recognised that causation in the logical or scientific sense is judged according to the so-called conditio-sine-qua-non formula (the 'but for test'). According to this test, an event is to be viewed as a cause if, without it, the result, in its specific form, would not 
occur $^{4}$. The act of an offender is therefore still a cause even if it in itself could not result in the damage but only in combination with the actions of another (so-called cumulative causation $)^{5}$.

In terms of greenhouse gas emissions and a particular event, the question would therefore be: would the specific event or change occur without anthropogenic emissions? The answer to this would be a probabilistic statement, not a clear yes or no - just as in the case of toxic substances. For many specific events, it can be argued that the probability of an event occurring without anthropogenic greenhouse gas emissions will be relatively low (see above).

It cannot be denied that questions of causation can belong to the biggest problems of environmental liability law (Staudinger and Kohler, 2010). The defendants in climate liability trials also see their best chances of defence in this area (Spieth and Hamer, 2009; Chatzinerantzis and Herz, 2010) even if others have shown - as is argued here - that causation can be shown using certain legal concepts.

One item of 'defence' should be ruled out at the outset, however. Defendants in a given case are likely to emphasise the similarity between climate change related damage and the forest damage caused by the so-called 'acid rain' [Chatzinerantzis and Herz, (2010), p.597] that initiated a broad debate on liability law in Germany and elsewhere in the 1980s. At the time it was accepted that air pollutants with a large-scale effect, particularly the sulphur dioxide and nitrogen oxide emissions from a very large number of larger and smaller sources (power stations, industrial plants, heating and traffic), had damaged a considerable part of the German tree population. The polluters, however, escaped liability because it was impossible to attribute the loss of a particular forest owner to one or more specific polluters ${ }^{6}$. But in the case of greenhouse gases, unlike the forest damage example, it can be shown that the gases are distributed evenly into the atmosphere and therefore, every molecule that is emitted, irrespective of where it actually comes from, contributes at least marginally to the greenhouse effect and thereby to the rise in temperature and its consequences [Frank, (2010), p.2298; Verheyen, (2005), p.248 ff].

The question therefore is: will a statement of probability be enough to establish causation 'beyond' the sine qua non-test?

Various theories to this end have been developed by lawyers in different jurisdictions. These include the 'proximity theory', the 'efficiency theory', the 'adequacy theory' and the 'foreseeability theory', but there is no agreement between domestic legal systems or in international law on the validity of these theories [Hart and Honoré, (1959), p.230]. Some domestic theories accept a 'contribution approach' to causation in fact, demanding only that the defendant's behaviour must contribute to the relevant outcome in a substantive way, i.e., the behaviour must lie above a de minimis threshold. This approach has also been termed 'proportional liability' [Verheyen, (2005), p.248ff]. Proportional liability is a concept applied in the already mentioned Toxic Torts and implies that a phenomenon cannot be attributed with full certainty but only within a range of probability. This concept was introduced specifically to apply the law to situations where a scientific certainty could simply never be ascertained in court [see Haritz, (2010), p.208 and $219 \mathrm{ff}]$.

In debating state responsibility under public international law, the International Law Commission, a UN Body has recognised, as a caveat to the state of international law on the issue, that "the allocation of injury or loss to a wrongful act [i.e., establishing causation between activity and damage] is, in principle, a legal and not only a historical 
or causal process" and that the issue cannot be solved "by search for a single verbal formula" (ILC, 2001).

At the same time, the major land mark case on environmental pollution, the 1941 Trail Smelter $\mathrm{Case}^{7}$ between Canada and the USA did not actually require proof of causation (of fumes by a factory in Canada) at all, but only referred to 'convincing evidence' regarding the damage itself (to farmers in the USA) (Drumbl, 2008). The fact that the injury was at least partially caused by the air pollution originating at the smelter in Trail, Canada appeared to be sufficient for the tribunal. The tribunal stated:

\begin{abstract}
"Where the tort itself is of such a nature as to preclude the ascertainment of the amount of damage with certainty, it would be a perversion of fundamental principles of justice to denie all relief to the injured person, and thereby relief the wrongdoer for making any amend for his acts, while the damage may not be determined by mere speculation or guess, it will be enough if the evidence show the extent of the damages as a matter of just and reasonable inference, although the result be only approximative."
\end{abstract}

This amounts to a substantial down-scaling of the importance of scientific causation. Also, it was the damage to US territory that was unlawful and decisive for the tribunal, not whether the activity under Canada's control was lawful or unlawful per se - a possible answer to one of the second bullet point of problems referred to above in the Introduction to this paper.

In other words: there is no legal clarity on this issue that could be displayed here. The question has not been answered by any court of law yet. In principle, however, the answer to the question whether establishing legal causation is possible remains affirmative. Everything else will depend on the specific case, legal theory, jurisdiction etc.

\title{
3.3 Courts on climate change
}

What is noteworthy in this respect however is that courts around the world have already ruled that anthropogenic climate change is happening. While the IPCC has used probability statements, such as

"There is very high confidence that the net effect of human activities since 1750 has been one of warming." [IPCC, (2007), p.5]

and still does this with respect to certain events, in its fifth assessment report it has also used language such as this:

"Human influence on the climate system is clear. This is evident from the increasing greenhouse gas concentrations in the atmosphere, positive radiative forcing, observed warming and understanding of the climate system." [IPCC, (2013), pp.2-14]

Courts have already accepted this statement without a probabilistic qualifier in Germany ${ }^{9}$ and the USA, where the Supreme Court held, inter alia:

"The harms associated with climate change are serious and well recognized. The Government's own objective assessment of the relevant science and a strong consensus among qualified experts indicate that global warming threatens, inter alia, a precipitate rise in sea levels, severe and irreversible changes to natural ecosystems, a significant reduction in winter snowpack with 
direct and important economic consequences, and increases in the spread of disease and the ferocity of weather events.". ${ }^{10}$

On 24th June 2015 the district court of the Hague accepted anthropogenic climate change even to an extent sufficient to order the Government to reduce emissions by $25 \%$ by 2020 (baseline 1990) (see for the full judgement http://www.urgenda.nl/en/, accessed 25 th June 2015).

There are many other example, including from developing countries ${ }^{11}$. The US Supreme Court even accepted causation statements with respect to sea level rise:

“According to petitioners' uncontested affidavits, global sea levels rose between 10 and 20 centimeters over the 20th century as a result of global warming and have already begun to swallow Massachusetts' coastal land..."

And while there has been no tort-like case actually decided on the merits, one could come forward any time, such as the case about Hurrican Katrina which has already seen numerous preliminary judgements including a brief by the Supreme Court of the USA denying appeal against a former order of court. The case was first filed in September 2005 with the District Court for the Southern District of Mississippi by several victims of "Katrina" ${ }^{12}$. So far, they have been denied a hearing on the merits, inter alia because "their injuries were not fairly traceable to the actions of coal, oil and electricity companies". The case is ongoing ${ }^{13}$, arguing that global warming has caused plaintiffs to incur higher insurance premiums and has lowered the resale value of their homes due to the increased risk of tropical storm activity, wind damage and flood damage.

Recent judgements on administrative law cases suggest that courts in the US do reckon that impacts due to climate change can technically be linked to emissions, however. In a case involving the Environmental Impact Assessment for a coal mine, the District Court of Colorado ${ }^{14}$ explicitly rejected the claim made by the defendant authorities that

"Predicting the degree of impact any single emitter of [greenhouse gases] may have on global climate change, or on the changes to biotic and abiotic systems that accompany climate change, is not possible at this time. As such, . . . the accompanying changes to natural systems cannot be quantified or predicted at this time."

While this case did not relate to causation in the sense of tort or nuisance, the line of reasoning in it certainly is in line to the reasoning on proportional liability explored above.

\section{Conclusions}

Going back to Section 2 above, the question is therefore not whether causation can be shown legally, but in what context this question is asked. Showing legal causation between anthropogenic climate change and a specific event or loss is undoubtedly difficult, but might not be needed to actually address loss and damage within the climate regime - as is the mandate for the Warzaw Mechanism on Loss and Damage. States have a legal duty to provide negotiated solutions where environmental damage is expected to occur, so that prompt and adequate compensation can be obtained in practice [Verheyen, (2005), p.330 ff]. This is a view supported by the International Law Institute and others (see also Kosolapova, 2013). 
What remains to be seen is whether and to what extent a reversal of the 'burden of proof' might be helpful for tackling loss and damage and to stop the uncertainties in detection and attribution science from diverting from the real issue, which is the general (ethical) question of responsibility for the impacts of climate change.

So far, as in any legal case, scholars have argued that because any loss will have so many contributing factors, the influence of climate change will not be detectable. Indeed, as a rule, it is the claimant who carries the burden of proof in relation to the cause of the damage. For some groups of cases, however, the law eases the evidential burden, even as far as to a reversal of the burden of proof. This is the case when the defendant breaches a protective or safety duty or (this forms a sub-category of such cases) exceeds specified emission limits ${ }^{15}$.

It seems plausible that this argument applicable to emission limits could be applied to establish a prima facie causal relationship between greenhouse gas emissions and the increased global mean temperature due to the anthropogenic greenhouse effect. This link is explicitly recognised in statutes, not only in Germany but around the world and forms the basis for the climate regime itself.

It is true that the International Court of Justice has just rejected the notion that the precautionary principle could lead to such a reversal ${ }^{16}$. Yet, in this case (Pulp Mills), there was no substantive law as clear as Art. 2 FCCC which not only accepts the relation between greenhouse gases and climate change, but also sets out that climate change can become 'dangerous'. Thus, it could be interesting to start asking the question in the reverse: would a loss have happened without the anthropogenic signal? Clearly, many more questions will arise from such an approach.

\section{References}

Allen, M. (2012) 'The scientific basis for climate change liability', in Lord, R. et al. (Eds.): Climate Change Liability, p. 8 ff, Cambridge University Press, Cambridge.

Allen, M. and Stott, P.A. (2003) 'Estimating signal amplitudes in optimal fingerprinting, part I: theory', Climate Dynamics, Vol. 21, Nos. 5-6, pp.477-491.

Brunnée, J. et al. (2012) 'Overview of legal issues', in Lord, R. et al. (Eds.): Climate Change Liability, p.33, Cambridge University Press, Cambridge.

Chatzinerantzis, A. and Herz, B. (2010) Climate Change Litigation - Der Klimawandel im Spiegel des Haftungsrechts, NJOZ, pp.594-598, Neue Juristische Online Zeitschrift, München.

Drumbl, M.A. (2008) Transboundary Harm in International Law Lessons from the Trail Smelter Arbitration, Cambridge University Press, Cambridge.

Field, C.B. et al. (2014) Climate Change 2014: Impacts, Adaptation and Vulnerability, Contribution of Working Group II to the Fifth Assessment Report of the Intergovernmental Panel on Climate Change, Vol. 1, Cambridge University Press, Cambridge, UK and New York, NY, USA.

Frank, W. (2010) Climate Change Litigation - Klimawandel und haftungsrechtliche Risiken, NJOZ, pp.2296-2300, Neue Juristische Online Zeitschrift, München.

Frank, W. (2013) Klimahaftung und Kausalität - Urteilsanmerkung zur Entscheidung des US Court of Appeals fort he Ninth Circuit vom 21.9.2012 im Verfahren Native City of Kivalina v., Exxon Mobil et al., ZUR, p.28, Zeitschrift für Umweltrecht, Baden-Baden.

Haritz., M. (2010) An Inconvenient Deliberation, the Precautionary Principle's Contribution to the Uncertainties Surrounding Climate Change Liability, p.212 ff, BOX, Leiden.

Hart, H.L.A. and Honoré, T. (1959) Causation in the Law, p.230, Oxford University Press, Oxford. 
ILC (2001) Chapter IV of the 'Report of the International Law Commission, 53rd session', General Assembly, Official Records, 56th session, Suppl. No. 10, UN Doc. A/56/10, 227 and 228, respectively.

IPCC (2007) Fourth Assessment Report 2007, Synthesis Report, Summary for Policymakers, p.5.

IPCC (2013) Fourth Assessment Report, Summary for Policy Makers, pp.2-14 [online] http://www.ipcc.ch (accessed 14.7.2014).

Koch, H-J., Lührs, M. and Verheyen, R. (2012) 'Germany', in Lord, R. et al. (Eds.): Climate Liability, p.376 ff, Cambridge University Press, Cambridge.

Kosolapova, E. (2013) Interstate Liability for Climate Change Induced Damage, Eleven International Publishing.

Lefeber, R. (2012) 'Climate change and state responsibility', in Rayfuse, R. and Scott, S.V. (Eds.): International Law in the Era of Climate Change, pp.321-349, Edward Elgar, Cheltenham.

Roderick, P. and Verheyen, R. (2008) Beyond Adaptation, Report for WWF.

Spieth, F. and Hamer, M. (2009) Potential Liabilities Arising from Climate Change, p.3, Freshfields Bruckhaus Deringer client briefing.

Stabinsky, D. and Hoffmaister, J (2014) 'Establishing institutional arrangements on loss and damage under the UNFCCC: the Warsaw international mechanism for loss and damage' [online] http://www.care.org/sites/default/files/documents/tackling-the-climatereality-2013.pdf (accessed 6 July 2015).

Staudinger and Kohler (2010) Kommentar zum Bürgerlichen Gesetzbuch mit Einführungsgesetz und Nebengesetzen, Buch 3, Sachenrecht, Umwelthaftungsrecht, Introduction Marginal No. 159.

Stocker et al. (2013) Climate Change 2013: The Physical Science Basis, Contribution of Working Group I to the Fifth Assessment Report of the Intergovernmental Panel on Climate Change, Cambridge University Press, Cambridge, UK and New York, NY, USA [online] https://www.ipcc.ch/report/ar5/wg1/ (accessed 6 July 2015).

Verheyen, R. (2005) Climate Change Damage in International Law, Brill, Leiden.

Verheyen, R. (2012) Tackling Loss \& Damage - A New Role for the Climate 2012 [online] http://www.lossanddamage.net/download/6877.pdf (accessed 6 July 2015).

\section{Notes}

1 This paper has been prepared in the context of the CDKN-funded activities on loss and damage led by Germanwatch e.V., Germany. See http://www.lossanddamage.net. The opinions expressed are solely those of the author.

2 All FCCC documents accessible on: http://www.unfccc.int. This mechanism seeks to "address loss and damage associated with impacts of climate change, including extreme events and slow onset events, in developing countries that are particularly vulnerable to the adverse effects of climate change" and is to be reviewed by COP 22 in 2016.

3 This method is explained in the IPCC 4th Assessment Report, Appendix 9A, 9 A 1 'optimal fingerprinting, http://www.ipcc.ch/publications_and_data/ar4/wg1/en/ch9s9.html. These studies are still rare, but they seek to detect the human signal in a specific event such as a flood or a heat wave.

4 BGH, 4 July 1994 II ZR 126/93, marg. no. 15.

5 BGH, 20 November 2001, VI ZR 77/00, marginal no 9.

6 BGH, 10 December 1987, III ZR 220/86, marg. no. 13.

7 Trail Smelter III RIAA (1941) 1911 at 1930f.

8 Trail Smelter Case, ibid, p. 1920. 
9 Bundesverwaltungsgericht, Federal Administrative Court, 8 C 13/05, Judgement of 25.01.2006, Bundesverfassungsgerich (Federal Constitional Court), 1 BvF 1/05, Judgement of 13.03.2007, LG Köln, 28 O 456/05, Judgement of 26 October 2005.

10 Supreme Court of the Unites States, Massachusetts et al. v. Environmental Protection Agency et al., No. 05-1120, 2 April 2007 - Massachusetts v. EPA, 127 S.Ct. 1438 (2007).

11 See for an in depth analysis of national jurisdictions such as Australia, China, India, Indonesia, Japan, Egypt, Israel, Kenya, South Africa, European Union, Germany, Poland, English law, Russia, Canada, USA, Brazil and Mexico, Lord et al. (2012).

12 Az. 1:05-CV-436 LG-RHW. See in depth Lührs and Verheyen, Klimaschutz durch Gerichte in den USA, ZUR 2009, pp.129-138.

13 On 27 May 2011 Comer v. Murphy Oil USA, Inc. was re-filed. The case was dismissed by a Mississippi Court in March 2012, but is under appeal to the USA Court of Appeals for the Fifth Circuit.

14 Civil Action No. 13-cv-01723-RBJ, High Country Conservation Advocates et al. v. USA Forest Service et al., 27 June 2014 ('arch coal').

15 See for a German example: BGH, 17 June 1997, VI ZR 372/95, marginal no. 11; BGH, 2 April 2004, V ZR 267/03, marginal no. 37.

16 ICJ, Pulp Mills on the River Uruguay (Argentina v. Uruguay), Judgment of 20 April 2010. 